
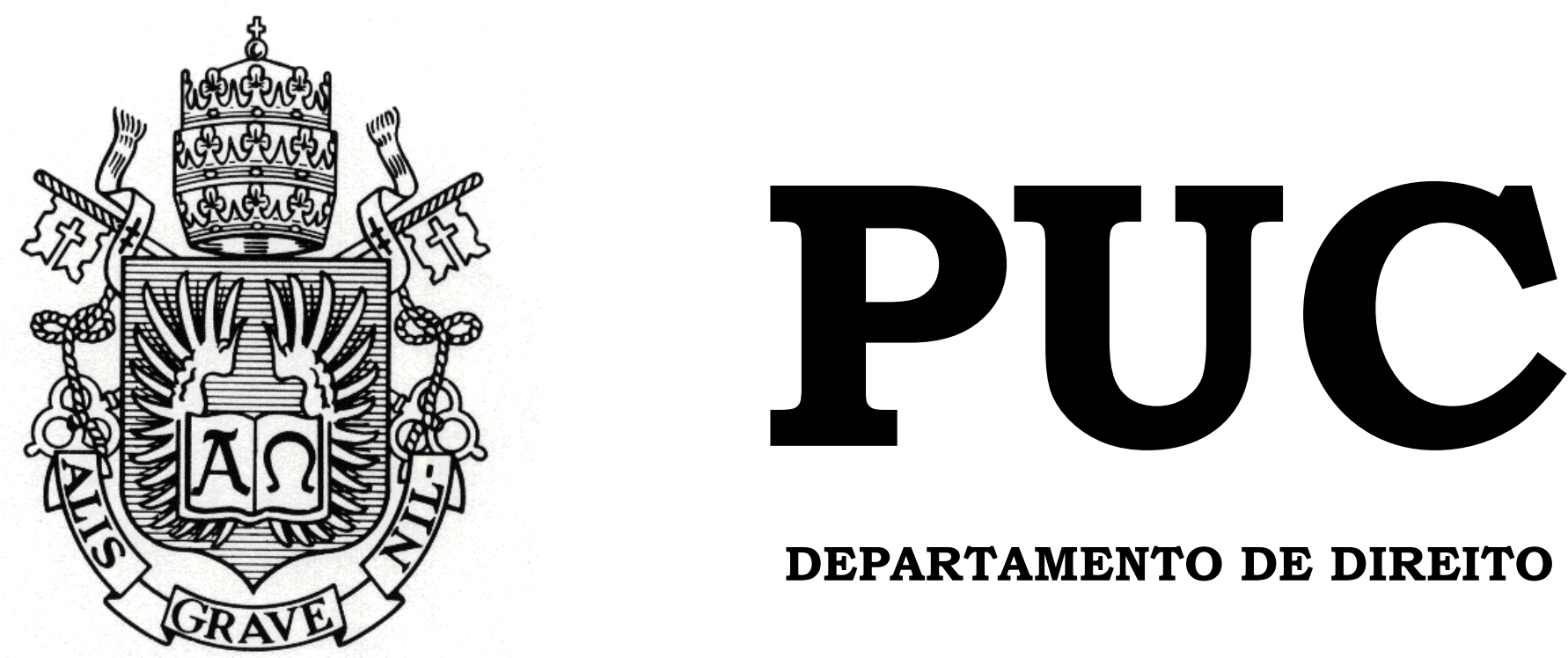

DEPARTAMENTO DE DIREITO

PRÁXIS INSTITUINTE E CO-CRIAÇÃO DO COMUM: A SUPERAÇÃO DO BINÔMIO PÚBLICO-PRIVADO COMO FORMA DE REALIZAÇÃO DE DIREITOS HUMANOS

por

LEONARDO VIEIRA DE OLIVEIRA

ORIENTADORA: Professora Dra. Bethania Assy 2019.1

PONTIFÍCIA UNIVERSIDADE CATÓLICA DO RIO DE JANEIRO RUA MARQUÊS DE SÃO VICENTE, 225 - CEP 22453-900 RIO DE JANEIRO - BRASIL 


\title{
PRÁXIS INSTITUINTE E CO-CRIAÇÃO DO COMUM: A SUPERAÇÃO DO BINÔMIO PÚBLICO-PRIVADO COMO \\ FORMA DE REALIZAÇÃO DE DIREITOS HUMANOS
}

\author{
por
}

LEONARDO VIEIRA DE OLIVEIRA

Monografia

apresentada

ao

Departamento de Direito da Pontificia Universidade Católica do Rio de Janeiro (PUC-Rio) para a obtenção do Título de Bacharel em Direito.

Orientadora: Professora Dra. Bethania Assy 
2019.1 
Aos meus pais, Mirian da Silva Vieira e José Hunaldo de Oliveira, que foram minha fortaleza por anos na busca do meu sonho mais subversivo: graduar-me em Direito pela PUCRio. 


\section{AGRADECIMENTOS}

A generosidade de pessoas e organizações foram fundamentais para garantir a continuidade

À querida Professora Bethania Assy, pela paciência, pela confiança e pelo acompanhamento da minha trajetória desde 2014.

Ao Leonardo Zuma, amigo de curso que diariamente me deu carona à Central do Brasil para que eu não perdesse o último ônibus para Queimados.

À TODXS, por me fazer acreditar que o comum se realiza no dia-a-dia.

Ao Fundo Emergencial de Solidariedade da PUC-Rio, pelo apoio com passagens e alimentação - decisivo para garantir minha permanência na universidade.

À Vice-Reitoria Comunitária da PUC-Rio, pela bolsa filantrópica integral para cursar a graduação em Direito.

Ao Professor José Ribas, pelos aprendizados mais valiosos sobre constitucionalismo latino-americano.

Ao Professor Eric Racine, coordenador do Núcleo de Neuroética do Institut de Recherches Cliniques de Montréal, por me acolher como pesquisador durante o verão de 2016.

Ao Professor Sam Potolicchio, da Universidade de Georgetown, pelas lições sobre diversidade cultural durante o Preparing Global Leaders Academy.

À equipe do Programa Jovens Embaixadores, por me fazerem acreditar que meus sonhos eram possiveis.

À Associação de Ex-alunos da Universidade Livre de Berlim, pela bolsa para estudar política comparada durante o inverno de 2015.

À equipe de bolsas da Universidad Autónoma de Madrid, que me permitiram um semestre de valiosos aprendizados em uma das melhores faculdades de direito europeias. 


\section{RESUMO}

Seguindo o conjunto de contribuições que Christian Laval e Pierre Dardot realizaram para a filosofia política e filosofia do direito no que diz respeito ao comum, a questão central explorada neste trabalho é: existem forças sociais, modelos alternativos, modos de organização e conceitos que nos permitam esperar algo além do capitalismo, fora das nossas concepções tradicionais de público e privado? A partir desta pergunta, nos debruçaremos sobre as formas como o comum surge enquanto princípio político das lutas contemporâneas, ressignificando o que tradicionalmente entendemos pelo termo e abrindo espaço para a realização de direitos humanos através de ações encarnadas na co-atividade de indivíduos engajados na mesma tarefa. Em suma, este trabalho tem como objetivo estudar o comum o propô-lo como princípio para orientar uma nova práxis instituinte.

Palavras-chave: comum, público, privado, co-atividade, práxis, direitos humanos. 


\section{SUMÁRIO}

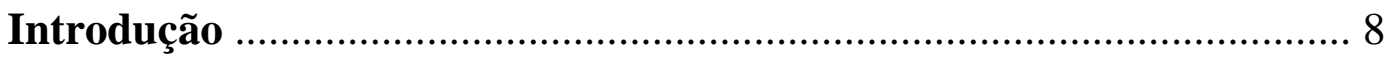

Capítulo 1 - Comum e Práxis: a Reabilitação de um Conceito ................. 12

Capítulo 2 - Da Captura do Estado à Emergência do Comum como Princípio da Lutas Concretas .......................................................................... 21

Capítulo 3 - Do Binômio Público-privado à Operacionalização dos

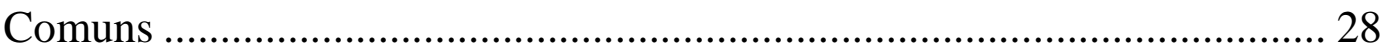

Capítulo 4 - Um Movimento Duplo ao Encontro do Comum .................. 38

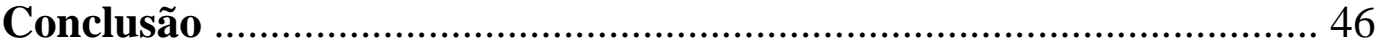

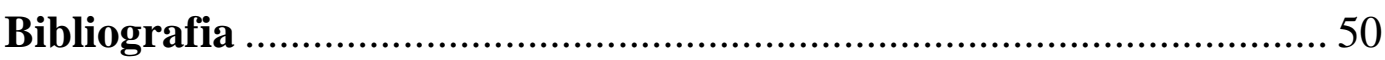




\section{INTRODUÇÃO}

O fim da segunda década do século XXI é marcada por momentos de estranheza, em que permanece o sentimento de que nada mais é possível frente à uma lógica implacável de exploração desenfreada, sustentando sociedades incapazes de solucionarem as crises e desastres que engendram. A precipitação de uma catástrofe ecológica, o enfraquecimento da massa de assalariados organizados, a ascensão do nacionalismo e do ódio contra identidades específicas são apenas exemplos de como uma racionalidade fundada na competição, na auto-superação e no crescimento indefinido coloca a humanidade diante de uma 'suspensão do porvir', onde a questão central que rumora é: existem forças sociais, modelos alternativos, modos de organização e conceitos que nos permitam esperar algo além do capitalismo?

Christian Laval e Piere Dardot, em sua obra Común ${ }^{1}$, levam a cabo o trabalho de examinar o quadro sintomático do mundo contemporâneo e conseguem diagnosticar com precisão as principais falhas do capitalismo e sua lógica produtivista. Em seguida, buscam entender como movimentos altermundialistas, que lutam contra esta lógica, podem ser abarcados por um princípio político ligado à própria ação política coletiva: o comum.

O atual estado do capitalismo conduz à destruição do planeta e do homem pelo homem. Ainda que o pós-Segunda Guerra tenha sido marcado por políticas redistributivas e sociais, o neoliberalismo que se espalha a partir da década de 80 estende a lógica da competição a toda a sociedade. Este sistema de normas que se instaura também se apodera do trabalho, dos comportamentos e das mentes, ordenando as relações das pessoas consigo mesmas e com os demais em função da lógica da auto-superação e do rendimento indefinido. Os autores identificam este momento histórico como a época do cosmocapitalismo, em que,

"mucho más allá de la esfera del trabajo, las instituciones, las actividades, los tiempos de vida, son sometidos a una lógica normativa general que los reconfigura y los orienta de acuerdo con los fines y los ritmos de la acumulación del capital". ${ }^{2}$

\footnotetext{
${ }^{1}$ LAVAL, Christian; DARDOT, Pierre. Común. $1^{\mathrm{a}}$ ed.. Barcelona: Gedisa, 2015.

${ }^{2}$ Ibid., p. 16.
} 
Ainda, esta mesma lógica precipita a crise ecológica, aproximando a humanidade do esgotamento de recursos, bem como avançando com o aquecimento global - problema mais importante e urgente que se coloca diante da humanidade, segundo o Programa das Nações Unidas para o Desenvolvimento (PNUD) e o Painel Intergovernamental sobre Mudanças Climáticas (IPCC). ${ }^{3}$ Neste contexto, a proteção de bens comuns é necessária para garantir a proteção da humanidade, especialmente da parcela mais pobre da população, que sofrerá primeiros os impactos. Welzer prevê que a consequência última desta atual tendência, se nada for feito, será uma completa guerra por recursos no século XXI. ${ }^{4}$

Esta 'tragédia do não comum'5, como descrevem Laval e Dardot, exige que desenvolvamos novas perspectivas, a fim de chegarmos a condições e formas possíveis de atuarmos em comum, extraindo os princípios capazes de orientar as lutas, vincular as práticas dispersas de forma que se possa adotar uma nova instituição geral das sociedades.

A reivindicação do comum nasce, em primeiro lugar, nas lutas sociais e culturais contra a ordem capitalista e o Estado empresarial. Trata-se do termo central na alternativa ao neoliberalismo, surgindo como princípio efetivo dos movimentos que há decênios têm resistido à dinâmica do capital e dado lugar a novas forma de ação e a discursos originais. Ao passo que o comum aparece como princípio que atravessa as lutas anticapitalistas, ele também 'volve la espalda' definitivamente ao comunismo estatal. $\mathrm{O}$ vocabulário em torno do comum é resgatado da ideia de commons pelos movimentos altermundialistas e ecologistas, em oposição a ideia de enclosures. ${ }^{6}$ Neste sentido, o comum já nasce como fora da lógica que exige uma conformação nas categorias de público ou privado - é um fenômeno que escapa deste binômio.

\footnotetext{
${ }^{3}$ PNUD. Índices e indicadores de desarrollo humano 2018. Disponível em .<http://hdr.undp.org/sites/default/files/2018_human_development_statistical_update_es.pdf >. Acesso em 10 mai. 2019.

${ }^{4}$ WELZER, Harald. Climate Wars: what people will be killed for in the 21 st century. $1^{\mathrm{a}}$ ed.. Cambridge: John Wiley \& Sons, 2015. p. 13.

${ }^{5}$ LAVAL, Christian; DARDOT, Pierre. Op. cit. p. 15.

${ }^{6}$ Ibid., p. 21.
} 
Estes commons têm sido objeto, ao mesmo tempo, de uma intensa reflexão teórica. Numerosos estudos empíricos, alguns deles por iniciativa de Elinor Ostrom, dedicaram-se às formas institucionais, às regras de funcionamento e aos instrumentos legais que permitem às comunidades gerir recursos de forma ordenada fora do mercado e fora do Estado, sejam eles recursos naturais ou comuns do conhecimento.

A expansão meteórica da internet nos últimos dois ou três décadas, bem como o surgimento de novas tecnologias (tais como blockchain ou internet das coisas) tornou possível visualizar novas possibilidades de cooperação intelectual e reciprocidade em escala mundial; acompanhado dos riscos que surgem às liberdades em razão da concentração do capitalismo digital na mão de grandes empresas de tecnologia e o controle as formas de controle exercitas pelos Estados.

Filósofos, juristas e economistas multiplicaram suas obras desde então, estabelecendo gradualmente um vocabulário cada vez mais rico nos estudos comuns. Michael Hardt e Antonio Negri, por sua vez, pioneiros na elaboração de uma teoria do comum, têm o mérito histórico de passar o plano de reflexão das experiências concretas dos bens comuns (plural) a uma concepção mais abstrata e politicamente ambiciosa do comum (no singular). ${ }^{7}$ Enfim, o comum tornou-se o nome de um regime de práticas, lutas, instituições e pesquisas que apontam para um futuro não capitalista.

Em primeiro lugar, o presente trabalho se propõe a revisitar o caminho realizado por Laval e Dardot, abordando os diferentes usos do termo comum ao longo de sua extensa tradição na filosofia, reabilitando o seu conceito enquanto práxis. Em seguida, a partir da refundação do conceito de comum de forma mais rigorosa, rearticular a ele as práticas que hoje em dia encontram nele seu sentido. Além disso, esta monografia entenderá as formas como o comum escapa do binômio público-privado e se operacionaliza no

\footnotetext{
${ }^{7}$ HARDT, Michael; NEGRI, Antonio. Commonwealth: el proyecto de una revolución del común. $1^{\text {a }}$ ed.. Madrid: Ediciones Akal, 2011.
} 
limiar destas dimensões - a partir de autores que estudam a operacionalização do comum. Por fim, vamos questionar se movimentos em direção ao comum permitem uma co-criação que pode funcionar como caminho para a realização de direitos humanos.

De maneira geral, este trabalho pretende fugir das categorias tradicionais do direito dogmático, permitindo-se pensar como a filosofia como a filosofia política do comum representa uma nova chave teórica para a fundamentação dos direitos humanos - na contramão das abstrações do sujeito de direitos e ao encontro de uma coletivização da experiência humana. 


\section{CAPÍTULO 1 - COMUM E PRÁXIS: A REABILITAÇÃO DE UM CONCEITO}

A fim de abrir o campo de possibilidades do comum como chave de leitura da contemporaneidade, é necessário recuperá-lo como conceito para que atenda às necessidades descritivas dos movimentos contemporâneos que se opõem à lógica capitalista. O presente capítulo se dedicará a revisitar os usos do comum como conceito em diferentes contextos, a fim de encontrar pontos de contato e rechaçar os aspectos deste uso que impedem a delimitação de um conceito verdadeiramente político.

É imprescindível preparar o terreno para a discussão teórica do comum como princípio das lutas atuais contra o capitalismo, procurando mapear aquilo que se pode esperar extrair deste conceito. $\mathrm{O}$ uso extensivo do adjetivo comum em expressões como bem comum ou bens comuns poderia fazer com que supuséssemos que diz respeito a qualquer coisa, um não conceito sem qualquer relevância. Para entender em que contexto histórico o comum se inscreve, bem como para se livrar das banalidades, confusões e contra-sensos, Laval e Dardot empregam o que vão chamar de uma arqueologia do comum. ${ }^{8}$

Recuperar a origem etimológica da palavra comum é essencial para que consigamos uma orientação mais decisiva para a presente investigação. Neste contexto, Émile Benveniste, indica que o termo latino munus pertence nas línguas indo-europeias a um vasto registro antropológico, dentro do qual designa um fenômeno social específico: pela sua raiz, remete a um tipo participar de prestações e contraprestações relacionadas a honras e vantagens vinculadas a cargos. Designa, então, inseparavelmente, o que há que cumprir ativamente (um ofício, uma função, uma tarefa, uma obra, um cargo) e o que é entregado em forma de presente e recompensa. ${ }^{9}$ Se compreende sobretudo que os termos communis, cummune, communia ou communio, formados todos eles com a mesma articulação de cun e munus, querem significar não

\footnotetext{
${ }^{8}$ LAVAL, Christian; DARDOT, Pierre. Op. Cit. p.27.

${ }^{9}$ Ibid., p. 28
} 
somente o que é "colocado em comum", senão também a quem têm "cargos em comum". O comum, o commune latino, implica, pois, certa obrigação de reciprocidade ligada ao exercício de responsabilidades públicas. ${ }^{10} \mathrm{~A}$ consequência que Laval e Dardot extraem é que o termo "comum" é particularmente apto para designar o princípio de uma coobrigação para todos aqueles que estão comprometidos com a mesma atividade. Portanto, há que entender o duplo sentido contido em munus: a obrigação e a participação em uma mesma tarefa ou mesma atividade. ${ }^{11}$

A partir disto, os autores traçam o caminho etimológico percorrido acerca da utilização do termo comum, destacando que a concepção latina de comum dialoga com concepção da instituição do comum (koinôn) e com "o pôr em comum" (koinônen) em Aristóteles. De acordo com a concepção aristotélica, são os cidadãos que deliberam em comum para determinar o que convém à cidade e o que é justo fazer. ${ }^{12}$ "Es matricial para nuestra propia elaboración de lo común: face de la práctica de la puesta en común la condición misma de todo lo común, en sus dimensiones afectivas y normativas". 13

Entretanto, a concepção de atuar em comum que pretendem elaborar a partir de Aristóteles é absolutamente incompatível com a redução que é feita nos discursos e usos mais recentes do adjetivo "comum". Neste sentido, dedicam-se a diferenciá-la de três tradições que permanecem presentes nas nossas representações de comum. (I) A primeira, essencialmente teológica, concebe o "comum" como finalidade suprema das instituições políticas e religiosas: a norma superior do "bem comum" (no singular) deveria ser o princípio da ação e de conduta dos que têm responsabilidade dos corpos e das almas. (II) A segunda é de origem jurídica e encontra em nossos dias uma forma de prolongamento em certo discurso econômico sobre a classificação

\footnotetext{
${ }^{10}$ BENVENISTE, Émile. O vocabulário das instituições indo-européias. v. 1. Campinas: Ed. da UNICAMP, 1995. p. 96-97.

${ }^{11}$ LAVAL, Christian; DARDOT, Pierre. Op. Cit. p. 29.

${ }^{12}$ ARISTÓTELES. A política. Trad. Nestor Silveira Chaves. Rio de Janeiro: Nova Fronteira, 2011. p. 246.

${ }^{13}$ LAVAL, Christian; DARDOT, Pierre. Op. Cit. p. 30.
} 
dos "bens" (no plural): tende a reservar a qualificação de "comum" a certo tipo de "coisas". Esta é, por exemplo, a orientação dos movimentos altermundistas, que quiseram promover "bens comuns mundiais" como a atmosfera, a água ou o conhecimento. (III) A terceira é de origem filosófica: tende a identificar o comum com o universal (o que é comum a todos), expulsando, às margens insignificantes do ordinário e do banal, aquilo do comum que resiste a tal identificação. ${ }^{14}$

A seguir, será mostrado como cada uma destas tradições se constitui e o obstáculo que apresentam para a elaboração de um conceito verdadeiramente político do comum.

Em primeiro lugar, revalorizar a noção teológico-política de "bem comum" coloca certo número de questões que geralmente não recebem o tratamento adequado, como, por exemplo, a de saber quem se encontra na posição de definir o que é "bem comum" ou estabelecer quem detém os meios efetivos de uma política supostamente conforme a dito "bem comum".

"En realidad, el recurso al bien común alimenta cierto número de postulados perfectamente antidemocráticos que atribuyen al Estado, a sabios o a expertos en ética, incluso a la Iglesia, el cuidado de decir de qué se trata." 15

A partir de alguns pontos de referência, é possível entender o duplo sentido do comum no Ocidente. Estado e Igreja disputaram seu monopólio, ainda que pouco a pouco se puseram de acordo sobre uma repartição de papéis.

\footnotetext{
"Se ve entonces que sería pecar de ligereza retomar hoy sin precauciones la noción teológico-política de bien común. Los autores que a ello se arriesgan ignoran por lo general de qué herencia es portadora: nada menos que de la represión de una concepción que hace de la praxis humana la fuente de las normas. Lejos de poder servir como emblema de la emancipación, dicha noción muy bien podría cubrir y justificar formas de dominación arcaicas, en la medida en que una institución como la Iglesia pretende todavía poseer el conocimiento del bien común y, en consecuencia, ejercer un magisterio sobre las relaciones sociales."16
}

\footnotetext{
${ }^{14}$ Ibid. p. 31

${ }^{15}$ Ibid. p. 32

${ }^{16}$ Ibid. p. 39.
} 
Hoje, enfrentamos algumas consequências tirânicas que isto tem em matéria de sexualidade, de matrimônio e de família. Convém recordar, por outro lado, que a doutrina social da Igreja, que sempre faz do bem comum seu primeiro princípio, soube compatibilizar, seguindo diretamente a doutrina escolástica tomista, a tese da origem divina do destino universal dos bens da terra com o direito de propriedade, a condução de um uso da propriedade para bem comum. Olhando para o avanço do capitalismo nos últimos séculos, o balanço histórico de tal doutrina é particularmente sombrio.

A segunda armadilha da qual todo pensamento em torno do comum deve se precaver é a que consiste em inscrevê-lo na essência de certas coisas externas ao homem, essência que impediria o homem de se apropriar delas.

\footnotetext{
"Convendremos en hablar de reificación en la medida en que lo común sería identificado con ciertas propiedades que poseerían tales cosas en sí mismas. El concepto a partir del cual se produce esta reificación es el concepto de cosa común (res communis) tal como éste se encuentra en el derecho romano. Dicho concepto jurídico es, por lo tanto, el que trataremos de explicitar en primer lugar."17
}

No fim das contas, esta categoria a parte que constituem as res communes revela a dificuldade do direito romano em conceber a relação destas coisas com a esfera do direito como tal. São concebidos mais como um enclave originário, na propriedade coletiva, da era primitiva da humanidade, não tanto como uma categoria plenamente jurídica: naquela época, com efeito, todas as coisas teriam sido comuns a todos os homens. ${ }^{18}$ Neste sentido, constituem um "recinto pre-jurídico en cuyo interior el derecho deja subsidio una naturaleza autónoma como en estado fosilizado."19

Mas deve-se acrescentar que este enclave tem uma função muito precisa, na medida em que constitui um modelo para as coisas públicas, especialmente rios, estradas, praças e teatros: à imagem das coisas comuns, que são oferecidas para o uso comum de todos, as coisas públicas destinam-

\footnotetext{
${ }^{17}$ Ibid. p. 40.

${ }^{18}$ CHARDEAUX, M. A. Les choses communes, $1^{\mathrm{a}}$ ed.. Paris: LGDJ, 2006. p. 135.

${ }^{19}$ Ibid. p. 211.
} 
se ao uso comum de todos, com a única diferença de que estas são depois separadas da esfera de apropriação por um ato de direito público, enquanto as primeiras, supostamente, eles são em virtude de sua natureza. É precisamente essa diferença irredutível que é mais significativa:

\footnotetext{
'Si las res communes son concebidas como cosas por naturaleza inapropiables, ello es precisamente porque no integran totalmente la esfera jurídica. A la inversa, si las res communes hubieran debido formar en Roma una categoría plenamente jurídica, su inapropiabilidad no se hubiera fundado verosímilmente en su esencia. ${ }^{20}$.
}

Não podemos ver de que maneira a noção de uma coisa que por sua natureza seria inestimável (res communis) poderia ter constituído uma categoria plenamente jurídica em tal contexto, já que todas as coisas reconhecidas pela lei se constroem em relação a um sujeito ou um processo. É uma noção concebida como "uma espécie de receptáculo" que reagrupa todas as coisas cuja incapacidade é baseada em sua natureza. ${ }^{21} \mathrm{O}$ que enfatiza, mais uma vez, é a persistência das dificuldades de qualificar legalmente as entidades naturais que preexistem à lei.

Consequentemente, poucas lições podem ser tiradas desta categoria que está no limite do jurídico. Não devemos tentar estender a categoria de "coisas comuns" que herdamos do direito romano. É melhor abandoná-la e renunciar, de uma vez por todas, à ideia de que há coisas que são inapropriáveis por natureza para fundar por juridicamente a inapropriabilidade.

O terceiro cuidado que precisamos tomar ao revisitar as concepções produzidas em torno do comum que representam tentativas de identificação do comum com o universal. Afinal, não poderíamos definir como humano o pertencimento à humanidade? Aquilo que temos em comum, para além de nossas diferenças, não seria suficiente para desenhar uma nova política mundial?

\footnotetext{
${ }^{20}$ Ibid. p. 134.

${ }^{21}$ LAVAL, Christian; DARDOT, Pierre. Op. cit. p. 45.
} 
A Antiguidade definitivamente não ignorou este fundamento do universal. Na filosofia ciceroniana, o comum se baseia na sociabilidade própria do gênero humano. O cristianismo prolongou da sua forma esta identificação do comum com o universal: é como criatura de Deus e animal racional que o homem aspira à santidade. ${ }^{22}$ No registro de uma tradição filosófica persistente, o comum seguiu designando o que se põe como fundamento de um co-pertencimento: "Así, desde el punto de vista de la filosofía política, lo común siempre parece que debe anteceder a las comunidades, representar su fundamento, el suelo, la raíz inmutable, la esencia, la naturaleza." ${ }^{23}$ Não faltam tentativas de definir um bem comum modernizado apoiando-se nas ciências e na psicanálise. Neste essencialismo, diferente do anterior, "a identidade interior do gênero supre a identidade material das coisas. ${ }^{24}$

Outro movimento, como descreve Laval e Dardot, em dado momento da história, a filosofia insistiu em separar o comum do universal, provocando uma desvalorização do primeiro em favor do segundo - de forma que o comum tenha passado a ser frequentemente identificado com o ordinário e o vulgar. ${ }^{25}$ Estas diferentes concepções exigem que aprofundemos melhor o delineamento teórico dos termos "comum" e "universal", bem como suas implicações, como será feito a seguir.

A polarização sofrida pelo termo "comum" é ainda mais percebida se for dada atenção à maneira pela qual foram feitas tentativas muito precoces de estabelecer uma distinção entre o comum e o universal. De fato, a distinção é mais antiga do que geralmente se acredita. Aristóteles havia distinguido muito claramente o geral ou o comum (koinon) do universal $(\text { katholou })^{26}$

\footnotetext{
${ }^{22}$ Ibid. p. 49.

${ }^{23}$ REVEL, J. Produire de la subjectivité, produire du commun: trois difficultés et um postscriptum un peu long sur ce que le commun n'est pas. Seminário Du publica au commun. Sessão de 5 de dezembro de 2010, p. 6.

${ }^{24}$ LAVAL, Christian; DARDOT, Pierre. Op. cit. p. 50.

${ }^{25}$ Ibid. p. 50.

${ }^{26}$ AUBENQUE, Pierre. Le problème de l'être chez Aristote: essai sur la problématique aristotélicienne. Paris: Presses universitaires de France, 2018. p. 210.
} 
Enquanto o universal é determinado pelos limites de um gênero (por exemplo, "homem ou animal"), o comum significa o que é comum a diferentes gêneros. Do ponto de vista da extensão do termo, então, o comum é superior ao universal. Isso explica que o mais comum, isto é, o que é 'transgenérico' ou comum a todos os gêneros seja ao mesmo tempo o mais indeterminado: assim, o ser em geral, que é "comum a todas as coisas", dado que todas as coisas são, não pode constituir um gênero na ausência da delimitação sem a qual não há gênero. Não há nada que seja excluído do ser e não há nada que seja superior ao ser. Nesse sentido, ser é certamente um termo comum, mas não universal. Mas, por outro lado, o universal é superior ao comum na medida em que ganha intensidade o que perde em extensão. Em suma, o universal está do lado da determinação, ao passo que o comum é sempre ameaçado pela indeterminação - quanto mais comum, mais indeterminado. ${ }^{27}$

O que resulta da abordagem de Aristóteles é que, stricto sensu, só existe ontologia do mais comum, sendo, a partir deste ponto de vista, o discurso sobre ser o mais vazio possível. Em resumo, ou o comum é identificado com o universal e se torna o objeto do discurso mais positivo que pode existir, o da ciência (porque só existe a ciência do universal), ou então permanece a generalidade vazia do que excede o universal, e então não há muito a ser dito sobre isso, exceto de um modo puramente negativo.

A única maneira de escapar do naturalismo e do essencialismo é abordar como princípio que não é em razão de seu caráter comum que certas coisas são, ou devem ser, coisas comuns, tampouco é em relação a sua 'identidade de essência' ou seu pertencimento ao mesmo gênero que os homens têm algo em comum, e não simplesmente algo comum. No sentido em que Laval e Dardot propõem, o comum não é confundido com uma propriedade compartilhada por todos os homens. Também não é sobre a humanidade como um coletivo, o que Kant chama de 'conjunto da espécie humana', ou o que todos os homens têm em comum, embora seja

\footnotetext{
${ }^{27}$ LAVAL, Christian; DARDOT, Pierre. Op. cit. p. 54.
} 
especificado que esse comum "não deve ser interpretado em termos de pertencimento': "El individuo humano no pertenece a la humanidad como pertenece a una familia, una tribu, una casta o un Estado-nación. Comparte una humanidad con todos los otros seres de su especie, lo cual es muy distinto." ${ }^{28}$ Pode-se dizer, certamente, que para esta humanidade, entendida como coletiva, corresponde um "Estado universal dos homens", mas com a condição de especificar que tal Estado tem realidade apenas no mundo suprassensível. ${ }^{29} \mathrm{Em}$ suma, o comum é não é a humanidade como essência moral ou dignidade (Menschheit), nem a humanidade como espécie (Menschengattung), nem a humanidade como capacidade de empatia com outros homens (Humanität), que não tem relação com a faculdade de pensar colocando-se no lugar dos outros. ${ }^{30} \mathrm{O}$ comum deve ser pensado como uma co-atividade, não como um co-pertencimento, co-propriedade ou copossessão. ${ }^{31}$

Contra estas formas de 'essencializar' o comum, contra todas as críticas do comum para reduzi-lo à qualidade de um juízo ou um tipo de homem, deve ser dito que só a 'atividade prática' faz com que as coisas se tornem comuns, assim como somente esta atividade prática pode produzir um novo sujeito coletivo, longe da concepção tradicional de que tal sujeito possa preexistir a tal atividade como titular de direitos. Se existe alguma "universalidade", só pode ser uma universalidade prática, isto é, de todos os indivíduos que estão, num dado momento e em determinadas condições, envolvidos na mesma tarefa. Pode-se repensar o comum apenas com a condição de romper com o 'face-a-face metafísico' entre o sujeito livre e a coisa material ao alcance de seu domínio soberano. ${ }^{32} \mathrm{O}$ comum é

"[...]el principio político a partir del cual debemos construir comunes y hacer con ellos para preservarlos, extenderlos y conseguir que sobrevivan. Es, por este mismo

\footnotetext{
${ }^{28}$ COLLIOT-THÉLÈNE, Catherine. La Démocratie sans demos. Paris: PUF, 2011. p. 138.

${ }^{29}$ Ibid. p. 137.

${ }^{30}$ Ibid. p. 132-133.

${ }^{31}$ LAVAL, Christian; DARDOT, Pierre. Op. cit. p. 57.

${ }^{32}$ Ibid, 58 e 59 p.
} 
motivo, el principio político que define un nuevo régimen de las luchas a escala mundial." 33

Uma vez delimitado um conceito que descreve o comum, desde já, como práxis, faz-se necessário explicar de que forma o comum emerge como um princípio das lutas contemporâneas, bem como explorar as formas que ele assume e permanece nas sociedades capitalistas.

${ }^{33} \mathrm{Ibid}, 59 \mathrm{p}$. 


\section{CAPÍTULO 2 - DA CAPTURA DO ESTADO À EMERGÊNCIA DO COMUM COMO PRINCÍPIO DE LUTAS CONCRETAS}

Entender o como o princípio das lutas contemporâneas pede que compreendamos com mais profundidade os processos que levaram ao fracasso do comunismo, bem como sua oposição a concepções originárias. Somente então, será possível vislumbrar de que forma se dá a atual emergência do comum.

\subsection{Da Comunidade de Vida à Associação de Produtores}

Ao definir comunismo, Durkheim diz que

"Su idea fundamental, que permanece igual en todo lugar bajo formas apenas diferentes, es que la propiedad privada es la fuente del egoísmo y que del egoísmo se deriva la inmoralidad. Ahora bien, tal proposición no apunta a ninguna organización social en particular. Si es cierta, se aplica a todas las épocas y a todos los países; se adecúa tanto al régimen de la gran industria como al de la pequeña. $\mathrm{Ni}$ siquiera se refiere a un hecho económico, ya que la propiedad es un hecho jurídico y moral, que afecta a la vida económica pero sin ser parte de ella. En suma, el comunismo se resume por entero en un lugar común de moral abstracta, que no es de ninguna época ni de ningún país." 34

Este tipo de comunismo aspira a organizar a existência de um grupo de homens sob a base da comunidade de bens e práticas de consumo. Adquire o aspecto de um ascetismo coletivo, de uma renúncia à propriedade pessoal com vistas a uma melhoria moral ou uma preparação para a salvação. Ao compartilhar os bens, o indivíduo se funde na unidade da comunidade para se purificar e se aperfeiçoar. Esta partilha permite a mudança do indivíduo, a sua melhoria moral e o seu progresso espiritual. O comunismo é inteiramente voltado para a rejeição da riqueza, na medida em que se suspeita que o interesse econômico seja um agente de dissolução da integridade do grupo. Por outro lado, a prática da partilhar, particularmente a que intervém no consumo coletivo dos bens coletivamente possuídos, é um meio de purificação, um vetor de saúde moral, do mesmo modo que no mundo cristão é uma via para a salvação religiosa. ${ }^{35}$

\footnotetext{
${ }^{34}$ DURKHEIM, Emile. El socialismo. Madrid: Ediciones Akal, 1987.

${ }^{35}$ LAVAL, Christian; DARDOT, Pierre. Op. cit. p. 74.
} 
Enquanto o antigo comunismo ainda era governado pela figura mais antiga da comunidade de bens, de acordo com a lógica da dívida simbólica, o socialismo moderno é governado pela figura da sociedade dos indivíduos, lugar de uma energia que exige organização, fontes de forças que devem ser coordenadas e de um poder próprio do qual seus membros devem se reapropriar. ${ }^{36}$ Nesse sentido, a distância entre um modelo e o outro deve-se ao fato de que o socialismo, assim como a sociologia, parte da sociedade como realidade sui generis, lugar de interações e movimentos que têm sua autonomia e exigem sua organização específica, original e racional. Trata-se de organizar 'forças sociais imanentes', dando-lhes uma força associativa apropriada à sua natureza. O socialismo e a sociologia são, nesse sentido, herdeiros dos inventores da 'sociedade civil', de essência econômica. Mas a 'sociedade' dos socialistas é separada de seu complemento político, o 'governo econômico', ainda muito parecido com os 'governos dos legalistas'. Esse lugar de poder separado da sociedade é dissolvido na 'associação de produtores', de tal maneira que a própria política está condenada a uma pura e simples extinção. ${ }^{37}$

\subsection{O comunismo de Estado e a Captura Burocrática do Comum}

$\mathrm{O}$ argumento central de Laval e Dardot no que concerne à relação entre revolução e Estado gira em torno dos conceitos de hipoteca comunista e captura burocrática do Estado - o primeiro faz referência à total desvinculação do comunismo de Estado da sua proposta originária, dando lugar ao terrorismo de Estado; o segundo abre o primeiro conceito e aprofunda a crítica, a fim de expor como o Estado-partido usurpou os ideais democráticos, colocando vidas humanas a serviço do totalitarismo. ${ }^{38}$

As experiências totalitárias engendradas pelo comunismo de Estado ao redor do mundo, tais como os regimes stalinista, maoísta e polpotista,

\footnotetext{
${ }^{36}$ TÖNNIES, Ferdinand. Communauté et société: catégories fondamentales de la sociologie pure. Presses universitaires de France, 2015.

${ }^{37}$ MARX, Karl. Miséria da filosofia. Boitempo Editorial, 2017.

${ }^{38}$ LAVAL, Christian; DARDOT, Pierre. Op. cit. p. 92-93.
} 
sinalizaram um rompimento sistemático com o ideal da emancipação encarnada pelo movimento obreiro, dando lugar à sinistra realidade do terror de Estado. As tentativas de reabilitação destes regimes, na busca de certa objetividade e no uso de um olhar comparado, insistem que a oposição ao capitalismo e ao neoliberalismo poderia alimentar contra-histórias que desmistificariam os fatos, porém, como argumentam os autores, estas tentativas não fazem nada senão banalizar as formas terroristas do comunismo burocrático. ${ }^{39}$

O ciclo de experiências comunistas que se iniciaram em 1917 revelaram defeitos acentuados do marxismo e da socialdemocracia, outorgando ao comunismo um aspecto sombrio e inédito: o de um Estado terrorista que adquiri monopólio da violência arbitrária e ganha mais força com o ganho do monopólio do discurso sobre o mundo, o pensamento, a arte e a cultura, culminando num controle absoluto do porvir das sociedades. As circunstâncias nas quais tais manifestações do Estado acontecem fomentam uma série de tentativas de justificação. O próprio Trotski, que foi eliminado pelo sistema terrorista, o havia justificado em resposta a Kautsky:

"El grado de encarnizamiento de la lucha depende de toda una serie de condiciones
interiores e internacionales. Cuanto más encarnizada y peligrosa se muestre la
resistencia del enemigo de clase vencido, más se transformará, inevitablemente, el
sistema de coerción en sistema de terror."

Entretanto, apesar da recorrência de tais tentativas de justificação nestas dadas circunstâncias históricas, as condições interiores e internacionais a que se referiu Trotski não são suficientes para explicar esta transformação do Estado. As decisões que levaram a cabo tal transformação foram, realmente, resultado da solapamento do movimento obreiro pelo partido, dando início a um ciclo de auto-justificação do uso da violência pelo Estado através do emprego ilegítimo da mensagem de emancipação presente na revolução em seu início. No fim das contas, o ideal democrático da livre

\footnotetext{
${ }^{39}$ Ibid. p. 94.

${ }^{40}$ TROTSKY, Leon. Terrorismo y comunismo: Slavoj Zizek presenta a Trotsky. Ediciones Akal, 2009.p. 91-92.
} 
associação dos produtores foi suplantada por formas de dominação e servitude, sem relação alguma com a cultura da crítica, a análise objetiva dos feitos e a rejeição dos dogmas que constituíam a ética intelectual de Marx. De modo geral:

\begin{abstract}
"La actividad democrática se ve rápidamente corrompida por dos formas de burocratización: desde arriba, consistente en que el partido coloniza los órganos populares hasta entonces autónomos; y desde abajo, que se traduce en el desarrollo de un aparato que suple a las asambleas generales. Esta doble "captura burocrática" de la democracia de los comités y los soviets desencadena, desde el principio de la revolución una monopolización por parte del Partido del poder efectivo, monopolización que reveló ser irreversible."41
\end{abstract}

A consequência mais clara da captura burocrática e sufocamento das forças democráticas é que a revolução, em vez de levar a cabo uma recuperação das forças sociais monopolizadas pelo Estado e pelo capital, desemboca na criação de um Estado controlado pelo Partido, ou seja, um Estado-partido que tem a pretensão de substituir as interações sociais e dirigir o seu desenvolvimento desde cima.

\begin{abstract}
"En otros términos, en este tipo de régimen los órganos del Estado ejercen su poder terrorista, como ojos y brazos que son del Partido esclarecido por la ciencia de la historia, un partido que pretende ser la fuente y el resorte de toda vida colectiva e individual, reduciendo esta última a una función económica programable." ${ }^{42}$
\end{abstract}

Enfim, pretendendo possuir e encarnar o saber histórico, o Partido e o Estado se atribuem a si mesmos o direito de impor À sociedade, por meio da força, a verdade da história. De outra forma, a lógica de partido reintroduziu o jogo da representação do soberano e o povo, de tal modo que a unidade deste último dependia da unidade de seu representante. Neste sentido, argumentam os autores, Hannah Arendt não se equivocava ao ver na ditadura do partido único o "último estadio del desarrollo del Estado-nación en general y del sistema multipartito en particular". ${ }^{43}$ No entanto, neste caso, não se tratou de qualquer partido, senão de uma forma particular de partido, que de entrada quis produzir a unidade do proletariado com o objetivo de

\footnotetext{
${ }^{41}$ LAVAL, Christian; DARDOT, Pierre. Op. cit. p. 95.

${ }^{42}$ Ibid. p. 96.

${ }^{43}$ ARENDT, Hannah. L'humaine condition. Paris: Gallimard, 2012. p. 570.
} 
conquistar o poder de Estado e que, uma vez realizado este objetivo, seguiu produzindo dita unidade mediante a organização do trabalho e da produção.

"La lógica del partido impuso pronto su propia dinámica institucional. Ésta hizo desempeñar al partido único el papel de instrumento de la creación de un común de producción que el capital aún no había podido constituir mediante su propio desarrollo nacional. Estas condiciones particulares explican que lo alzamientos que buscaban romper el monopolio estatal de lo común trataran de hacer reconocer lo común de la democracia, incluso en su forma más directa, también en la esfera de la producción, vale decir, en el terreno mismo donde el monopolio se ejercía con la mayor violencia en la vida cotidiana de millones de individuos." ${ }^{44}$

O comum, pelo menos no sentido de uma obrigação que todos impõem a si mesmos, não pode ser postulado como uma origem a ser restaurada, nem considerada imediatamente dada no processo de produção, nem imposta externamente, de cima para baixo. O importante, antes de tudo, é prestar atenção à última parte desta conclusão: a suposta 'realização' do comum na forma de propriedade do Estado só pode significar a destruição do comum pelo Estado. Consequentemente, se alguma coisa comum sobreviveu, apesar de tudo, sob formas subterrâneas nas sociedades dominadas pela dita propriedade, estava pagando o preço de uma resistência a essa submissão pelo Estado.

\subsection{O Retorno dos Comuns}

Laval e Dardot sustentam que o surgimento e a difusão mundial da reivindicação dos comuns estão ligados a uma série de lutas que, desde meados da década de 1990, compartilham o fato de se opor a aspectos particularmente prejudiciais e intoleráveis das políticas neoliberais. ${ }^{45}$ Estas lutas são o grande exemplo de formas de poder e movimentos que se opõe, ao mesmo tempo, às relações sociais capitalistas baseadas na propriedade privada dos recursos e aos modos tradicionais de gestão burocrática dos bens "públicos".

\footnotetext{
${ }^{44}$ LAVAL, Christian; DARDOT, Pierre. Op. cit. p. 99.

${ }^{45}$ Ibid. p. 124
} 
Sem dúvidas, nas lutas daquele tempo, permanecia uma forte crença nas soluções estatais, administrativas e centralizadas, que eram maciçamente as da esquerda no século XX. Mas, ao mesmo tempo, a reconfiguração do Estado-empresa, aliado aos oligopólios e submetido às organizações do Consenso de Washington ou da União Européia, pressiona pela busca de outras formas políticas.

A extensão e o sucesso da categoria dos comuns, que já faz parte do léxico do protesto antiglobalização, deve-se em parte ao seu caráter sedutor e 'flutuante'. Os textos hesitam entre o plural 'comuns' ou 'bens comuns' e o singular 'bem comum'. ${ }^{46}$ Mas o significado que reveste o termo comuns é, por hora, profundamente crítica - pois expressa, em primeiro lugar, uma rejeição da grande apropriação neoliberal e, em segundo lugar, afeta as próprias justificações do capitalismo. Protestar contra o enclosure dos comuns significa retomar a crítica da propriedade privada como uma condição absoluta da riqueza social. ${ }^{47}$

As lutas contemporâneas marcadas pela reivindicação dos comuns vão se globalizando por si próprias: estruturam-se setores e organizam, nos lugares centrais das cidades (a 'praça'), a reunião e o encontro entre todos aqueles que são afetados pelas políticas neoliberais. Basicamente, é esta necessidade muito prática de uma resistência global que explica o surgimento da categoria dos comuns desde a década de 1990. Designa os modos de resistência mais diversos à sujeição da sociedade, da subjetividade e da vida ao capital. A palavra 'commons' é uma senha, um emblema. Mas, como essa categoria parece representar elementos já presentes, dados na natureza, na sociedade e na inteligência, encontra seus limites na heterogeneidade dos bens. ${ }^{48}$ Neste sentido, no próximo capítulo, será necessário entender as formas como o comum pode ser de fato operacionalizado, atendendo a determinados critérios e regras que atendam às suas peculiaridades, mas que,

\footnotetext{
${ }^{46}$ Ibid. p. 126.

${ }^{47}$ Ibid. p. 127.

${ }^{48}$ Ibid. p. 155.
} 
em todos os sentidos, escapam das nossas concepções tradicionais de público e privado. 


\section{CAPÍTULO 3 - DO BINÔMIO PÚBLICO-PRIVADO À OPERACIONALIZAÇÃO DOS COMUNS}

Neste capítulo, a chave central para pensar o comum é a própria possibilidade, trazida especialmente por autores norte-americanos, de pensar uma gestão comum dos recursos, deslocada da relação tradicional de oposição entre mercado e Estado. A partir destas concepções, será possível, em seguida, explorar de que forma o comum ganha concretude como instrumento de realização de direitos humanos.

A aposta é importante: consiste em superar a distinção, constitutiva do nosso pensamento jurídico e econômico, entre bens privados e públicos, entre mercado e Estado. Esta oposição ainda está muito presente nos movimentos de protesto. Denunciar a mercantilização do mundo muitas vezes leva a se contentar com a defesa dos serviços públicos nacionais ou a apelar para a extensão da intervenção estatal. Por mais corretos que sejam os seus argumentos, esta alegação permanece no domínio do adversário, recusando questionar um antagonismo constituído, precisamente, para tornar o mercado a regra e o Estado a exceção. Essa posição, que concebe o Estado como lugar de resistência à invasão do mercado, justifica duplamente a divisão do trabalho entre mercado e Estado, porque reconhece a esfera de cada um. ${ }^{49}$

Neste sentido, Laval e Dardot destacam que a teoria econômica, desde 1950, admite absolutamente a legitimidade da produção pública ou governamental com o pretexto de que certos bens corresponderiam por sua natureza à propriedade privada, enquanto que os outros corresponderiam também de forma natural à ação estatal. A Economia Política dos Comuns procura, então, na busca por sair desta oposição entre mercado e Estado, explorar novos caminhos teóricos e práticos para a reformulação da teoria econômica tradicional.

\subsection{A Tragédia dos Comuns}

\footnotetext{
${ }^{49}$ Ibid. p. 157.
} 
Para entender o que está em jogo nesta economia dos comuns deve resituá-la no âmbito de um amplo debate que emergiu no trono de 'A tragédia dos comuns ${ }^{50}$ por Garrett Hardin. Este autor, em 1968, acreditava poder demonstrar que as terras comunais, antes mesmo do movimento dos enclosures, haviam sido destruídas pela superexploração a que haviam sido submetidas pelos criadores de ovelhas, guiadas por seu único interesse egoísta.

O pensamento de Hardin é baseado no postulado da racionalidade do comportamento do Homo economicus, que não pode ou não quer levar em conta todos os efeitos de uma exploração desenfreada de um recurso comum. Este famoso texto trata da superpopulação, considerada pelo malthusiano Hardin como o problema número um da humanidade. ${ }^{51}$

Ele imagina, a fim de ilustrar sua tese, uma exploração de pastagens deixadas com acesso aberto, na qual os pastores 'racionais' teriam interesse em aumentar sem limite o número de cabeças de gado, o que levaria fatalmente à utilizado excessiva das terras comunais pelo gado.

De fato, o que Hardin chama de 'comum' é uma mescla de casos muito diferentes. Laval e Dardot argumentam que ele confunde, acima de tudo, essas 'coisas' com a livre exploração sem restrições de bens retirados de um estoque limitado disponível. O argumento de Hardin se baseia, de fato, num sofisma que consiste em introduzir em seu modelo um comportamento economicamente 'racional', isto é, motivado apenas pela lógica do interesse pessoal, em um contexto normativo que exclui precisamente tal comportamento, porque as regras dos comuns são feitas para evitar o risco de superexploração. A fábula de Hardin, portanto, não é suficiente para conceber a existência de uma 'economia moral' - de acordo com as palavras de Edward P. Thompson ${ }^{52}$ - que governa as regras consuetudinárias de uso

\footnotetext{
${ }^{50}$ HARDIN, Garrett. The tragedy of the commons. science, v. 162, n. 3859, p. 1243-1248, 1968.

${ }^{51}$ LAVAL, Christian; DARDOT, Pierre. Op. cit. p. 166.

52 THOMPSON, Edward P. The moral economy of the English crowd in the eighteenth century. Past \& present, n. 50, p. 76-136, 1971.
} 
comum, que é uma contradição fundamental do ponto de vista da visão histórica. $^{53}$

De qualquer forma, o postulado de Hardin foi importante para formatar o discurso econômico dominante que impregnou o debate público e a elaboração teórica, contribuindo amplamente para construir a ideia que hoje em dia se costuma ter do comum. A economia política estabelece, assim como o direito, em termos de bens - ainda que a definição que ambas as disciplinas dão a esse respeito seja diferente. No campo jurídico, os ativos são definidos como coisas apropriáveis, o que também é o caso, por outro lado, da contabilidade. Na economia padrão, um bem econômico é considerado como tal pela satisfação que faz de uma necessidade, pelo tipo de consumo a ele vinculado e, consequentemente, pela lógica de sua produção, comercial ou não. O comum é, portanto, uma propriedade dos bens, e não uma propriedade das instituições. No entanto, os comuns (commons) não podem ser reduzidos a bens comuns (common goods). ${ }^{54}$

O economista raciocina com base em um duplo postulado sobre a natureza intrínseca dos bens e sobre o comportamento do Homo economicus, que supostamente justificaria a distribuição da produção de bens e serviços entre o mercado e o Estado. ${ }^{55}$ Mas, na realidade, as coisas não acontecem de acordo com um raciocínio que exclua a política ou a ética da definição de ativos. O fato de que é o Estado ou o mercado que fornece um bem não se dá exclusivamente devido à sua natureza, mas a fatores políticos, culturais, sociais e históricos que não podem ser esquecidos pela teoria, como a economia padrão faz.

\subsection{A Instituição dos Comuns}

Na contramão do pessimismo em torno dos comuns sustentado pela tragédia dos comuns, há aqueles preocupados em entender como institucionalizar o comum como forma de operacionalizá-lo. Em poucas

\footnotetext{
${ }^{53}$ LAVAL, Christian; DARDOT, Pierre. Op. cit. p. 166.

${ }^{54}$ Ibid. p. 161.

${ }^{55}$ Ibid. p. 164.
} 
palavras: os comuns são instituições que permitem o gerenciamento comum de acordo com regras multiníveis, estabelecidas pelos mesmos 'apropriadores'. Benjamin Corial propõe a definição de comuns imobiliários (communs fonciers), segundo sua própria fórmula, como 'conjuntos de recursos governados coletivamente, por meio de uma estrutura de governança que garante a distribuição de direitos entre os partenaires que participam do comum (commoners) e tem como objetivo a exploração ordenada do recurso, permitindo sua reprodução a longo prazo. ${ }^{56}$

Existem formas coletivas na sociedade para chegar a um acordo e criar regras de cooperação que não podem ser reduzidas ao mercado e à liderança do Estado. E isso é demonstrado empiricamente nos numerosos casos de grupos que dispensaram perfeitamente a coerção estatal ou a propriedade privada para evitar a famosa tragédia dos comuns.

A representante mais conhecida desta corrente é Elinor Ostrom, Prêmio Nobel de Economia em 2009, que teve como objeto as condições práticas e institucionais que permitem gerir recursos em comum. ${ }^{57}$ Ostrom reconhece que há também outros bens mistos, que são chamados de 'bens comuns' (common goods), que são ao mesmo tempo não exclusivos e rivais, como zonas de pesca, pastos abertos, sistemas de irrigação, isto é, bens cujo acesso dificilmente pode ser proibido ou restringindo, a menos que as regras de uso sejam estabelecidas. Estes ativos são aqueles que Ostrom chamou de common-pool resources (CPR). ${ }^{58}$ Esses bens podem ser objeto de uma exploração individual, mas se expõem ao risco de uma diminuição, inclusive um esgotamento da quantidade global do recurso se cada um trata de maximizar sua utilidade pessoal. ${ }^{59}$

Deste ponto de vista, o institucionalismo de Ostrom afasta-se do individualismo metodológico dominante e retira da sociologia seu modelo do

\footnotetext{
${ }^{56}$ CORIAT, B. Coriat. De communs fonciers aux communs informationnels. Trait communs et différences. Intervenção no seminário internacional Propriété et Communs, les nouveaux enjeux de l'accès et de l'innovation partagés. París, 25 e 26 de abril de 2013.

${ }^{57}$ OSTROM, Elinor. Governing the commons. Cambridge: Cambridge University Press, 2015.

${ }^{58}$ Ibid.

${ }^{59}$ LAVAL, Christian; DARDOT, Pierre. Op. cit. p. 165.
} 
indivíduo socializado e da psicologia cognitiva sua teoria da aprendizagem. ${ }^{60}$ Trata-se de uma arte social, à qual Elinor Ostrom dá o nome de crafting, termo que se refere ao hábil trabalho do artista e do artesão, que se distingue da aplicação de um sistema de regras imposto a partir de cima ou de fora por especialistas e sábios.

Elinor Ostrom, tomando as ferramentas dos teóricos da ação racional, pensa em instituições em termos econômicos de 'capital social', tão indispensáveis quanto o capital físico para a existência do comum. ${ }^{61} \mathrm{No}$ entanto, além deste vocabulário econômico, o processo de crafting das instituições é, na verdade, profundamente sociológico e político. O conjunto de incentivos à cooperação mobiliza um saber próprio do grupo social que lida com o comum e, muitas vezes, envolve condições políticas externas que permitem e estimulam o autogoverno.

Entretanto, uma observação feita pelos autores, que será base para crítica, é que Ostrom utiliza uma racionalidade econômica na qual o comum pode ser dito como tal porque é naturalmente comum. Trataria-se, portanto, de uma tipologia de bens estabelecida de acordo com critérios técnicos: haveria bens que por sua natureza seriam comuns e, em consequência, adequados para uma gestão coletiva, assim como outros por sua natureza são bens públicos ou privados, devido a suas particularidades intrínsecas.

As consequências deste fundo naturalista não são menores e vão em direções distintas. Se o comum é uma dimensão natural de certos bens, este pode justificar que existe, em meio ao oceano de bens proporcionados pelo mercado e pelo Estado, uma economia especial que deveria ser preservada para respeitar a especificidade dos bens comuns. ${ }^{62}$ Nisto, a tese não tem nada de revolucionária, sendo, inclusive, bastante conservadora. Mas em um sentido muito distinto, se se consegue demonstrar que os bens mais essenciais

\footnotetext{
${ }^{60}$ CHANTEAU, Jean-Pierre; LABROUSSE, Agnès. L'institutionnalisme méthodologique d'Elinor Ostrom: quelques enjeux et controverses. Revue de la régulation. Capitalisme. Institutions, pouvoirs, n. 14, 2013.

${ }^{61}$ KEOHANE, Robert O.; OSTROM, Elinor. Local commons and global interdependence. Londres: Sage, 1994. p. 125 e seguintes.

${ }^{62}$ LAVAL, Christian; DARDOT, Pierre. Op. cit. p. 159.
} 
para o funcionamento da economia e da sociedade são por natureza comuns, pareceria ter-se resolvido ao mesmo tempo a questão da saída do capitalismo. Esta é, argumentam os autores, a tendência que foi seguida por boa parte da reflexão crítica contemporânea. Segundo André Gorz, por exemplo, ao falar da gratuidade que se estende no âmbito da economia do conhecimento, afirma:

"La informática e internet socavan el reino de la mercancía en su misma base. Todo lo que se puede traducir a lenguaje digital es reproducible, comunicable sin costo, tiende irresistiblemente a convertirse en un bien común, incluso en un bien común universal cuando es accesible a todos y todos pueden utilizarlo. Se trata de una ruptura que mina la base del capitalismo." 63

Em resumo, limites dessa nova economia institucional dos bens comuns devem-se, em última análise, ao fato de que ela não se libertou completamente das hipóteses fundamentais que estão na base da teoria dos bens privados e públicos. ${ }^{64}$ Continua prisioneira do postulado segundo o qual a forma e a estrutura da produção dos bens devem depender das qualidades intrínsecas dos próprios bens. Deste ponto de vista, a resposta que a teoria econômica dos comuns deu à tese de Hardin permanece problemática. Enquanto os recursos naturais cujo estoque é limitado podem ser objeto das instituições descritas nas investigações, os outros bens, supostamente, seriam naturalmente produzidos de forma mais eficiente pelo mercado ou pelo Estado. Por outro lado, esta discussão ganha outros contornos quando falamos de comuns do conhecimento.

\subsection{Conhecimento, internet e comum}

As práticas de 'colocar em comum' através da disseminação de trabalhos científicos ou artísticos, através da criação de software livre, a construção de enciclopédias colaborativas, são hoje tantos exemplos destes ‘novos conhecimentos comuns' que são colocados em prática e refletem um

\footnotetext{
${ }^{63}$ GORZ, A. Écologica. París: Galilée, 2007. p. 37-39.

${ }^{64}$ LAVAL, Christian; DARDOT, Pierre. Op. cit. p. 179.
} 
compromisso compromisso social e de reciprocidade. ${ }^{65}$ Neste sentido, seria o conhecimento naturalmente comum?

Esta é lição que Ostrom e Hess retiram da sua análise do marco dos comuns do conhecimento, apesar de seu ponto de partida ser mais uma vez muito naturalista e contra a ideologia espontânea dos hackers, onde a liberdade de trocas suporia ausência de regras. Se domínios importantes do conhecimento já foram reduzidos a elementos mercantis ou estão sob a ameaça de serem assim, também vale a pena destacar com Elinor Ostrom e seus colaboradores que eles podem ser reorganizados como comuns no plano legal se quisermos libertá-los da lógica proprietária, mesmo do domínio capital direto e exploração comercial. Assim, os pesquisadores que desenvolveram a noção de "comuns do conhecimento" basearam-se, inicialmente, no princípio da auto-organização do trabalho em comum, favorecido pelas novas tecnologias da informação, e estabeleceram um conjunto de regras que permitem o funcionamento dessas comunidades. ${ }^{66}$

A Internet, pela sua profusão, pela multiplicidade e diversidade de seus participantes, constitui, sem dúvida, um conjunto de recursos produzidos e colocados em comum pelos internautas que produzem trocas constantes. Mas será a rede, como se pergunta Mikhail Xifaras, um espaço libertador e emancipatório que nos livrará da propriedade privada e nos fará passar do capitalismo cognitivo para o 'comunismo informacional'? ${ }^{67} \mathrm{~A}$ característica desses movimentos, e em particular do software livre, é que eles encontraram uma gama de proteções legais para evitar os efeitos negativos da dimensão de exclusividade constitutiva de uma propriedade intelectual que tende a ser imposta como o direito usual em todo o campo imaterial. As licenças de software livre e do código aberto constituem a base constitucional do comum do conhecimento em todas as suas formas, da Arte livre ao open access de estudantes universitários e pesquisadores, e revelam

\footnotetext{
65 Ibid., 182

${ }^{66}$ HESS, Charlotte; OSTROM, Elinor. Understanding knowledge as a Commons. Massachusetts: MIT Press, 2007. p. 5.

${ }^{67}$ XIFARAS, Mikhaïl. Le copyleft et la théorie de la propriété. Multitudes, n. 2, p. 50-64, 2010.
} 
ser a condição matricial de uma criação de riqueza coletiva por uma comunidade de usuários. ${ }^{68}$ A questão que se coloca é se a resposta dos defensores do software livre e do código aberto à extensão da propriedade intelectual é um modelo generalizável que permitirá opor-se ao domínio da lógica proprietária, não apenas no domínio digital e informacional, mas em todos os setores de produção, dando forma a uma sociedade de um novo tipo.

Para o filósofo Pekka Himanen, o espírito hacker é uma nova ética de trabalho que coloca a busca por eficiência e lucro em segundo lugar, em favor da paixão e da solidariedade. ${ }^{69}$ Alguns não hesitam em traçar o retrato do hacker como 'anti-homo economicus'. ${ }^{70} \mathrm{Em}$ oposição ao trabalhador alienado da indústria, o hacker seria um artista do comum que traria ao mundo uma nova estética criativa de orientação coletiva. Seria inscrito em uma dinâmica cuja justificativa um tanto idealizada não deixa de lembrar os discursos dos grupos da vanguarda artística no século XX. ${ }^{71}$ Essa nova ética de trabalho, segundo Himanen, estaria suplantando a moralidade puritana feita de sacrifício e renúncia, e se espalharia progressivamente por toda a economia, a ponto de deixar vislumbrar um novo espírito geral capaz de remodelar um sistema econômico. ${ }^{72}$

Nesse sentido, a ética hacker desempenha uma função muito similar às normas coletivas que orientam o estabelecimento de instituições e das regras para os comuns naturais. O que podemos destacar, em resumo, é que as práticas que foram desenvolvidas no domínio de programas gratuitos, mídias participativa, sites colaborativos, bancos de dados compartilhados etc., mostraram que os fatores sociais, cívicos e éticos desempenham um papel fundamental na criatividade intelectual e estética necessária para a

\footnotetext{
${ }^{68}$ ANDERSON, Chris. Makers: a nova revolução industrial. Tradução de: SERRA, ACC Rio de Janeiro: Elsevier, 2012. p. 5.

${ }^{69}$ PEKKA, Himanen; LINUS, Torvalds; MANUEL, Castello. The hacker ethic and the spirit of the information age. Londres: Secker \& Warburg, 2001.

${ }^{70}$ RHEINGOLD, Howard. The virtual community: Homesteading on the electronic frontier. MIT press, 2000.

${ }^{71}$ DUSSOLIER, S.. Open source and copyleft. Authorship reconsidered?. New York: Columbia Journal of Law and Arts, n 26, 2002-2003. p. 281 e seguintes.

${ }^{72}$ PEKKA, Himanen; et. al. Op. cit.
} 
produção digital de alguns bens e serviços ${ }^{73}$ Esta demonstração prática foi realizada contra a concepção dominante, segundo a qual somente o estímulo financeiro garantido pela propriedade e domínio do conhecimento é efetivo.

No entanto, cabe ressaltar, a identificação do usuário da internet, a coleta de informações pessoais, a espionagem generalizada por empresas e agências de informação, tudo isso foi sobreposto ao 'código primitivo' e modificou a natureza do ciberespaço. Lutar pela liberdade na Internet é, portanto, defender a liberdade pessoal contra a dupla ameaça do poder corporativo e da vigilância governamental. Mas é também defender um espaço de partilha não governado pela lógica do mercado e pela censura política do Estado.

Este capitalismo cognitivo, que vê na exploração do trabalho colaborativo de programas livres uma espécie de protótipo econômico, estende-se à medida que as empresas compreendem a importância econômica das comunidades virtuais. Com este novo modo de produção, baseado na interconexão das inteligências através da rede, criam-se as condições de uma superação do capitalismo. ${ }^{74}$ André Gorz, por vezes, caiu nesta armadilha tecnicista quando sustentou, por exemplo, que "o computador revela ser uma utilidade universal, universalmente acessível, mediante o qual todos os saberes e todas as atividades podem, em princípio, serem postas em comum". ${ }^{75}$ Encontram-se aqui, mais uma vez, forças utópicas por vezes antigas, cujo princípio recorrente é extrapolar os efeitos de determinados sistemas organizacionais ou dispositivos técnicos para torná-los modelos de organização da sociedade. Seja organização industrial em Saint-Simon ${ }^{76}$ ou a cibernética em Nobert Wiener ${ }^{77}$ um século depois, trata-se em cada ocasião de formas econômicas e técnicas que servem como ponto de apoio para projeções futuristas de reorganização social completa.

\footnotetext{
${ }^{73}$ LAVAL, Christian; DARDOT, Pierre. Op. cit. p. 199.

${ }^{74}$ Ibid. p. 204.

${ }^{75}$ GORZ, A. Gorz. L'Immatériel. Connaissance, valeur et capital. Paris: Galilée, 2003. p. 21.

${ }^{76}$ SAINT-SIMON, Henri. El sistema industrial. Madrid: Edicones de la Revista de Trabajo, 1975.

${ }^{77}$ WIENER, Norbert. Cibernética: ou controle e comunicação no animal e na máquina. São Paulo: Polígono, 1970.
} 


\subsection{Uma nova teoria}

O surgimento do 'paradigma dos comuns' deve muito a Ostrom. Ao mostrar que as ameaças que se põem à repartição livre dos recursos intelectuais estão todas ligadas à natureza das regras de uso explícitas e implícitas, formais ou informais, atuais ou potenciais, que as destroem o impedem seu desenvolvimento, permite compreender o caráter perigoso dos comportamentos econômicos guiados pela lógica da apropriação, que esgotam irremediavelmente os recursos naturais.

Por outro lado, destaca os riscos de subprodução intelectual e cultural ligados a uma privatização do conhecimento que ameaça a criatividade e a comunicação, dificultando a coprodução de ideias e obras, bem como o uso do patrimônio público. Em ambos os casos, a análise convida a procurar as regras que permitam uma proteção contra esses perigos. Neste ponto, Elinor Ostrom, embora seja extremamente prudente em termos das conclusões práticas a serem tiradas de sua análise, não ignorou as possíveis consequências políticas de seu trabalho. Uma vez salientou, dando assim razão para Hardin quanto à extensão destas consequências, que os dilemas dos comuns não diziam respeito somente aos recursos locais de pequenas comunidades, senão também numerosos problemas associados aos países e ao mundo, sejam políticos, sociais, ecológicos ou militares, funcionavam de acordo com a terrível lógica do dilema do prisioneiro, que se impõe aos indivíduos presos em sua racionalidade estritamente individual e incapazes de encontrar uma solução cooperativa: “o mundo depende em grande medida dos recursos que estão sujeitos à possibilidade de uma tragédia dos comuns". ${ }^{78}$ Esta última é sempre, portanto, uma tragédia de cooperação impossível quando os indivíduos são prisioneiros do seu próprio interesse. Mudando as questões principais da produção para as instituições, Ostrom iniciou, sem concluir, a crítica do naturalismo econômico; sobretudo, fez do comum uma dimensão ética e um princípio do atuar, uma lógica que reclama uma nova teoria.

\footnotetext{
${ }^{78}$ OSTROM, E. Op. cit. p. 3.
} 


\section{CAPÍTULO 4 - UM MOVIMENTO DUPLO AO ENCONTRO DO COMUM}

O comum, portanto, surge como uma estratégia descritiva para uma multiplicidade de movimentos descentralizadores, que pulverizam a tomada de decisão e colocam em cheque a própria concepção de Estado na sua forma atual. Nos termos de Ostrom em seus últimos trabalhos, é necessário entender o comum como um princípio ético da ação, o qual vai nos permitir construir espaços de gestão comum de recursos.

Faz-se necessário reconhecer que as causas para esta transição e que permitem um ressurgimento da concepção de comum nas sociedades capitalistas modernas é (1) a mudança das condições materiais do mundo, impulsionada pelo avanço tecnológico e progressiva democratização do acesso à internet; (2) esgotamento das estruturas tradicionais de Estado, marcado pela captura burocrática do Estado definida nos termos de Larval e Dardot nos capítulos anteriores. Estas causas também acabam formatando a maneira como a produção de comuns vai se dar concretamente, à margem do público-privado e com traços profundamente inovadores.

Ao passo que supera o binômio público-privado, o comum afirma somente a co-atividade como fundamento da obrigação política. Entretanto, esta superação se dá a partir do público e a partir do privado, gerando um duplo movimento que ressignifica práticas dos domínios público e privado ao encontro do comum. A despeito da existência de vocabulário jurídico preciso para dar conta destas novas formas de organização, elas fazem uso do que está posto para inovar na produção de ações coletivas.

Serão apresentadas duas organizações que, no Brasil, tem sido representantes deste duplo movimento. A TODXS ${ }^{79}$, enquanto associação sem fins lucrativos, utiliza tecnologia e inovação para a promoção de direitos humanos de pessoas LGBTI+, na busca de um Brasil verdadeiramente inclusivo - já tendo sido indicada ao Google Play Awards na categoria

\footnotetext{
$79<$ www.todxs.org>
} 
impacto social. Utilizando fortes conexões com empresas, a TODXS redireciona investimentos de grandes empresas e os transforma em impacto social, representando um movimento que, do privado, vai ao encontro do comum. De outro lado, vamos o Colab ${ }^{80}$, uma startup de governo que se apresenta como uma rede social para a cidadania. O Colab permite que cidadãos fiscalizem, proponham e avaliem diversos serviços da cidades, estados e país dos usuários, - neste sentido, dando início a um movimento que parte do domínio público ao encontro do comum. Foi eleito o melhor aplicativo urbano do mundo pela New Cities Foundation.

Estas iniciativas se enquadram em um marco teórico definido por Laval e Dardot em sua obra Común, precisamente em suas propostas políticas para a realização do comum. Os autores definem 10 propostas políticas e, dentre elas, duas serão abordadas aqui: 'Proposta Política 5: A associação na economia deve preparar a sociedade do comum'; 'Proposta Política 7 - Os serviços públicos devem converter-se em instituições do comum'.

\subsection{Associação na Economia para Inclusão LGBTI+}

A luta a travar no seio da economia social diz respeito ao estabelecimento de formas democráticas de avaliar a 'utilidade social' do projeto e a atividade da associação, que deve ser determinada democraticamente e envolvendo seus atores, funcionários ou usuários. A economia social, sob certas condições, pode desafiar o monopólio da definição do interesse geral do Estado e o valor por parte do mercado. É assim que a economia social poderia demonstrar seu caráter potencialmente subversivo: já não é possível medir o valor da riqueza produzida mediante o preço das mercadorias ou como equivalente a um preço de mercado, como ocorre na produção pública. Jean Gadrey, fazendo a síntese de várias iniciativas desde o final de 1990, propôs uma série de critérios que permitem apreciar a contribuição das associações para a sociedade. Organizações que contribuem para

$80<w w w . c o l a b . r e>$ 
"a redução das desigualdades econômicas e sociais poderiam ser consideradas de utilidade social, também através da afirmação de novos direitos, à solidariedade (nacional, internacional ou local) e sociabilidade, aà melhoria das condições de desenvolvimento humano sustentável (no qual a educação, a saúde, a cultura, o meio ambiente e a democracia estão incluídos)." ${ }^{\circledR 1}$

Nos critérios adotados, é possível observar a importância adquirida pela 'produção do vínculo social'. Mas a utilidade social não diz respeito apenas ao impacto da ação na sociedade, sua avaliação também deve levar em conta o efeito direto sobre aqueles que nela participam. Seria paradoxal julgar essa contribuição sem incluir aqueles voluntários, funcionários, assalariados e beneficiários, que estão envolvidos em uma coprodução que os afeta mutuamente. ${ }^{82}$

Mas, é possível refazer a sociedade a partir da economia social? Em suma, este pluralismo teria o valor da exemplaridade, ao mostrar que a cooperação é melhor socialmente e com frequência também economicamente se comparada à hipercompetitividade. A economia social term, assim, múltiplas vantagens e virtudes: é um contrapeso ao mercado e limita seu campo, melhora qualitativamente a intervenção pública por meio de sua capacidade de 'inovação social' e realiza uma tarefa educacional desenvolvendo o espírito de solidariedade e da responsabilidade do cidadão. ${ }^{83}$

"La creación de organismo cooperativos y de asociaciones libremente elegidas,
autoorganizadas y autogestionadas al margen del mercado lucrativo y del Estado
en el dominio de la alimentación, de la educación, del cuidado de los niños, del
hábitat o del ocio, parece en efecto relanzar el gran sueño de la constitución de
enclaves emancipados en el seno de la sociedad." 84

Obviamente, essa estratégia depende, acima de tudo, do desejo de 'fazer e viver algo mais' em escala maciça. Supõe condições materiais, institucionais e subjetivas que, embora não sejam todas reunidas na

\footnotetext{
${ }^{81}$ GADREY, Jean. L'utilité sociale en question: à la recherche de conventions, de critères et de méthodes d'évaluation. Les dynamiques de l'économie sociale et solidaire, Paris, La Découverte, coll.«Recherches, p. 237-279, 2006. 2006, p. 278.

${ }^{82}$ LAVAL, Christian; DARDOT, Pierre. Op. cit. p. 570-572.

${ }^{83}$ Ibid. p. 572.

${ }^{84}$ Ibid. p. 573.
} 
atualidade, poderiam ser realizadas através do efeito de um entusiasmo coletivo para realizar aquela 'outra coisa' que faz sentido, ou pela rejeição de formas capitalistas e mercantis de produzir e trocar, já insustentáveis ecologicamente e psicologicamente repulsivas.

A TODXS, startup social sem fins lucrativos brasileira, tem buscado realizar inovação social enquanto associação sem fins lucrativos através do uso de tecnologia para a inclusão de pessoas LGBTI+ brasileiras. Olhando para os dados que enquadram o Brasil como o país mais violento do mundo para pessoas LGBTI+, a organização surgiu com o objetivo de informar pessoas LGBTI+ sobre legislação protetiva existente em seus estados, através da criação de um aplicativo de consulta de leis e canal de denúncias. Neste sentido, a TODXS existia apenas como um 'braço informativo' daquilo que já era tutelado pelo Estado, ou seja, leis estaduais e municipais que puniam pessoas e estabelecimentos com multas administrativas em razão de homotransfobia.

A trilha percorrida pela organização só obteve sucesso graças a um modelo de trabalho voluntário remoto, que permitiu que pessoas LGBTI+ em todo o Brasil e em outros países do mundo se engajassem pela causa, atuando em times onde todas as interações se davam por aplicativos de mensagem, email e videoconferências. Deste modo, foi possível atrair pessoas que representavam uma diversidade gigantesca e que ocupavam diferentes lugares ao longo do espectro social, econômico e demográfico brasileiro. Somente assim, foi possível garantir participação interseccional que fosse verdadeiramente representativa da multiplicidade de identidades de gênero e orientações sexuais.

Neste termos, defendo que a TODXS começava um movimento de aproximação do comum, uma vez que ressignificava o trabalho à medida em que este se transformava em uma obrigação política daquelas pessoas engajadas pela transformação do Brasil em um país inclusivo. Com o aplicativo, a TODXS cumpria somente o papel de disseminar informações sobre direitos humanos de pessoas LGBTI+, não extrapolando aquilo que, 
em tese, já era responsabilidade do Estado por lei. No entanto, em um segundo momento, aproveitando o crescimento da organização e a horizontalidade inerentes a sua composição, a TODXS foi capaz de experimentar mais de 10 projetos voltados para a inclusão de pessoas LGBTI+ - criando desde inteligências artificiais para atender pessoas em situação de risco, à criação de um programa de desenvolvimento de lideranças LGBTI+ para promover a inclusão no longo prazo.

Esta transição ecossocial, de acordo com os princípios da autoorganização, cooperação e multi-atividade, como Gorz pensava, apresenta, no entanto, um perigo: o isolamento em experiências resumidas em sua própria exemplaridade e separadas do resto. Christian Arnsperger está entre os que mais se interessaram pelo problema da transição para uma sociedade pós-capitalista. ${ }^{85}$ A nova democracia política, econômica e social implica optar por uma vida simples, mais autônoma e baseada na convivência, o que poderia traduzir-se em criar comunidades locais mais habitáveis do que as grandes metrópoles dominados pelos ritmos e estruturas do capitalismo mundial.

O acúmulo de práticas alternativas tem efeitos de educação e subjetivação que podem auxiliar sua possível tradução política e sua generalização. ${ }^{86}$ Porque a coisa mais interessante sobre essas práticas talvez não seja a sua retirada do mundo, mas a atração muito mais ampla que elas podem ter nas subjetividades. Nesse sentido, seria conveniente refletir sobre todas as formas de construção de políticas sociais e públicas que atribuam às associações um papel ativo, permitindo que a população se mobilize e participe das decisões que lhes dizem respeito.

\subsection{Desenhando serviços públicos participativos}

Laval e Dardot argumentam que conceber o comum como princípio político não significa que temos que esperar que o Estado proteja e amplie

\footnotetext{
${ }^{85}$ ARNSPERGER, Christian. Ethique de l'existence post-capitaliste: pour un militantisme existentiel. Paris: Le Cerf, 2009. p. 246-457.

${ }^{86}$ LAVAL, Christian; DARDOT, Pierre. Op. cit. p. 574.
} 
indefinidamente a propriedade pública, para desenvolver um pouco mais o domínio da administração burocrática sobre a sociedade e a economia. $\mathrm{O}$ socialismo da associação no século XIX e o comunismo dos concílios do século XX procuravam precisamente separar, opondo-as, a forma institucional a ser adquirida pelo socialismo e a gestão burocrática da economia pelo Estado. ${ }^{87}$ Mas esses movimentos, com raras exceções, não previram o desenvolvimento do chamado 'serviço público' na França. Esse desenvolvimento teve um efeito na direção oposta ao socialismo, acentuando no período entre guerras sua tendência ao estadismo e ao centralismo. ${ }^{88}$

Interrogar o papel dos serviços públicos na produção comum não é nada evidente. Há um sentimento, frequentemente fundado, de que não há tarefa mais urgente do que defender os serviços públicos das políticas neoliberais. O que se chama hoje de 'reforma do setor público' vai no sentido da mutação neoliberal do Estado, com os fenômenos que a acompanham: a precarização dos empregos públicos, o reforço da arbitrariedade hierárquica, o enfraquecimento das capacidades de negociação do funcionários, destruição dos últimos grupos que resistem no seio do aparato estatal, do hospital público e das coletividades locais. Mas opor-se a qualquer evolução democrática dos serviços públicos por meio de um reflexo da 'defesa do Estado’ seria igualmente arriscado. ${ }^{89}$

Não seria mais uma questão de conceber o Estado como uma administração centralizada gigantesca, mas como garantia final dos direitos fundamentais dos cidadãos no que diz respeito à satisfação de necessidades coletivamente consideradas essenciais, enquanto a administração de serviços seria confiada a organismos que incluem representantes do Estado, mas também de trabalhadores e cidadãos-usuários. ${ }^{90}$

\footnotetext{
${ }^{87}$ PANNEKOEK, A. 'La propriété publique et la propriété commune'. Publicado inicialmente na revista Western Socialist, novembro de 1947. Disponível em:

<http://bataillesocialiste.wordpress.com>

${ }^{88}$ LAVAL, Christian; DARDOT, Pierre. Op. cit. p. 585.

${ }^{89}$ Ibid. p. 586.

${ }^{90}$ FOURNIER, Jacques. Economie des besoins $\left(L^{\prime}\right)$ : Une nouvelle approche du service public. Paris: Odile Jacob, 2013.
} 
Nesta esteira, o Colab, startup de governo brasileira, cumpre o papel de conectar indivíduos ao setor público, garantindo uma participação direta no atendimento das demandas da população com o uso de tecnologia. Tratase de um aplicativo onde as pessoas podem ativar tomadores de decisão no poder público para pressionar por mudanças na cidade, voltadas para saneamento, educação, segurança, saúde etc. Escolhido o melhor app urbano do mundo, lidera uma série de iniciativas que têm como objetivo promover uma descentralização da Administração Pública e, ao fazê-lo, produz o comum a partir do público.

Atuando em importantes municípios brasileiros como Recife, Teresina, Maceió, Niterói e Contagem, o Colab promove maior integração e operacionaliza uma democracia mais participativa. É importante notar que, graças às mudanças materiais que permitiram o surgimento de tais tecnologias, torna-se possível a quebra de modelos tradicionais e engessados de hierarquia administrativa, morosidade estatal e subversão da estrutura burocrática do Estado na

Hoje, o Colab se propõe a conseguir transformar o Estado através de 5 eixos de transição: transição de gestão fechada para gestão transparente; gestão fragmentada para gestão integrada; gestão reativa para gestão responsiva; e gestão rígida para gestão experimental. Ao provocar estas mudanças, o Colab se enquadra em sua completude à descrição de Laval e Dardot do comum como um princípio de co-atividade que engaja indivíduos na realização de uma mesma tarefa.

Em suma, argumenta Laval e Dardot, a sociologia funcionalista não podia considerar o Estado como ele é, um campo complexo de forças e lutas atravessado por conflitos de interesses e valores, e não um 'órgão', um 'aparato' ou uma máquina definida por sua funcionalidade única. Em geral, o conceito sociológico de serviço público fingia ignorar as classes sociais e não queria ver na sociedade mais que um organismo que poderia certamente ter disfunções, mas que nãos estava inerentemente dividida e em conflito. ${ }^{91}$

\footnotetext{
${ }^{91}$ LAVAL, Christian; DARDOT, Pierre. Común. $1^{\text {a }}$ ed.. Barcelona: Gedisa, 2015. 592 p.
} 
Ao conceber a sociedade como uma cooperativa já realizada ${ }^{92}$, Duguit não podia imaginar que o estado conservaria todos os atributos de dominação sobre a sociedade, com os perigos que isso implica: violação das liberdades, tratamento desigual, ação policial arbitrária, desequilíbrios na justiça, e até mesmo o saque da coletividade com a venda de domínio público e tratamento favorecido. No seu otimismo positivista, não poderia imaginar que o Estado seguiria sendo considerado na cultura jurídica como um poder público soberano.

Consequentemente, não podemos ficar satisfeitos em recuperar o discurso idealizado do Estado sobre si mesmo. Mais do que simplesmente seguir a linha de defesa dos serviços públicos, seria uma questão de transformar os serviços através da criação de órgãos democráticos que deem aos profissionais, mas também aos cidadãos que são os destinatários desses serviços, um direito de intervenção, deliberação e de decisão, evidentemente respeitando as leis gerais e no sentido da missão própria deste tipo de serviços. Recuperando uma expressão com seu sentido já desgastado, tratase de uma verdadeira 'democracia participativa'.

${ }^{92}$ DUGUIT, Lon. Manuel de droit constitutionnel. BiblioBazaar, LLC, 2009. p. 299. 


\section{CONCLUSÃO}

Na presente monografia de conclusão de curso, partimos do fato de que estado do capitalismo está conduzindo à destruição do planeta e do homem pelo homem. O período pós-Guerra, apesar de ter sido marcado pela introdução de políticas redistributivas e sociais, o neoliberalismo que se espalha a partir da década de 80 estende a lógica da competição a toda a sociedade. Este sistema de normas que se instaura também se apodera do trabalho, dos comportamentos e das mentes, ordenando as relações das pessoas consigo mesmas e com os demais em função da lógica da autosuperação e do rendimento indefinido.

Neste sentido, ao debruçarmo-nos sobre a obra de Christian Laval e Piere Dardot, pudemos recuperar um exame detalhado do quadro sintomático do mundo contemporâneo, buscando definir o comum como um princípio político que (1) foge das categorias tradicionais do direito dogmático, ampliando as chaves de leitura dos movimentos atuais e (2) pode abrir um novo vocabulário para a fundamentação dos direitos humanos - contramão das abstrações do sujeito de direitos e ao encontro de uma coletivização da experiência humana.

No primeiro capítulo, foi realizado um diagnóstico do conceito de comum, a fim de afastar aquelas compreensões que nos impedem de enquadrá-lo como um princípio político. Opusemo-nos a todas as tendências à essencialização do comum, refutando as concepções que reduzem o comum à qualidade de um juízo ou um tipo de homem. Pois somente a 'atividade prática' faz com que as coisas se tornem comuns, assim como somente esta atividade prática pode produzir um novo sujeito coletivo, longe da concepção tradicional de que tal sujeito possa preexistir a tal atividade como titular de direitos. Se existe alguma "universalidade", só pode ser uma universalidade prática, isto é, de todos os indivíduos que estão, num dado momento e em determinadas condições, envolvidos na mesma tarefa.

No segundo capítulo, buscamos delimitar o comum para além das experiências fracassadas de comunismo que foram profundamente marcadas 
por uma captura burocrática do Estado. Em suma, entendemos que o comum designa os modos de resistência mais diversos e que, no entanto, é uma categoria que parece representar elementos já presentes, dados na natureza, na sociedade e na inteligência, encontrando seus limites na heterogeneidade dos bens. Neste sentido, é importante reforçar que o comum só se dá concretamente, a partir do momento que elementos na natureza, na sociedade e na inteligência são postos em comum.

No terceiro capítulo, vemos de que forma o comum poderia ser operacionalizado, apresentando a tradição institucional grandemente representada por Ostrom, que se utiliza de um vocabulário econômico para falar na possibilidade de uma gestão comum de recursos. Nesta esteira, Ostrom explicita que o processo de crafting das instituições é, na verdade, profundamente sociológico e político. $\mathrm{O}$ conjunto de incentivos à cooperação mobiliza um saber próprio do grupo social que lida com o comum, permitindo e estimulando o autogoverno.

No quarto capítulo, finalmente, foi possível analisar práticas no Brasil que reverberam o comum da filosofia política e do direito de Laval e Dardot, expressando especificamente duas propostas políticas que os autores propõem em seu livro. A TODXS mostra como práticas alternativas tem um feito fundamental na educação e na subjetivação, gerando uma atração ampla no conjunto de subjetividades e abrindo espaço para uma potencial tradução política e generalização. O Colab mostra que não é suficiente ficarmos satisfeitos em recuperar o discurso idealizado do Estado sobre si mesmo. Mais do que simplesmente seguir a linha de defesa dos serviços públicos, é preciso transformar os serviços através da criação de órgãos democráticos, o que tem sido feito por meio de tecnologia.

O comum se realiza na contramão do capitalismo e orientado para produção de coletividades, utilizando forças de descentralização e colaboração. Fica claro que o comum exige uma co-atividade para a sua produção, desenvolvida por indivíduos engajados no mesmo momento na mesma tarefa. Neste sentido, a produção do comum dispensa a existência de 
um sujeito pretérito titular de direitos. Não se trata de abandonar a tradição dos direitos positivados - pois ainda existem como uma garantia mínima de legitimidade e pretensão à proteção do Estado -, mas é possível extrapolálos pela promoção de uma 'tutela' profundamente conectada com as necessidades concretas das pessoas envolvidas na produção do comum.

É possível afirmar o comum como um caminho de realização de direitos humanos, mas, em outro sentido, o comum pode superar a extensão da tutela definida pela principiologia constitucional e dos tratados internacionais. O comum extrapola o modelo institucional do Estado garantidor de direitos fundamentais e avança para uma verdadeira tutela das necessidades reais e concretas de grupos definidos e enquadrados numa multiplicidade de identidades. Não se trata de um abandono do Estado ou de um esvaziamento do Estado na sua responsabilidade de garantir direitos fundamentais, mas da criação de ferramentas que aceleram o combate a desigualdades e injustiças. Por duas razões, (1) o comum não nasce de procedimentos institucionais burocráticos e pré-estabelecidos. (2) existe uma identidade entre obrigação e cumprimento no comum, que se dá no momento da sua produção, isto é, as obrigações uns com os outros surgem na prática como quando a TODXS entendeu sua vocação para além de um aplicativo informativo de direitos.

O comum ele surge como conjunto de práticas que se colocam desde já entre o público e o privado. Porque não possuímos amplo vocabulário jurídico para defini-lo como prática (fora da concepção tradicional de bens), quando ele se dá, ou é puxado para se enquadrar em uma das categorias jurídicas disponíveis, ou permanece de forma orgânica e informal. No campo dogmático, práticas instituintes do comum tem se dado no âmbito privado, através da utilização de formas de constituição possíveis - como no caso das associações sem fins lucrativos.

O comum surge como oportunidades de redirecionar a história para um modelo mais democrático e participativo - tendo em vista estarmos vivendo em período estratégico de muitas transformações tecnológicas, 
mudanças tecnológicas que permitem formas de organização antes inconcebíveis. Neste sentido, mais do que a forma jurídica, o comum pode ser identificado na medida em que propõe novas práticas que, em alguma medida, permitem o vislumbre de um futuro emancipatório. 


\section{BIBLIOGRAFIA}

ANDERSON, Chris. Makers: a nova revolução industrial. Tradução de:

SERRA, ACC Rio de Janeiro: Elsevier, 2012.

ARNSPERGER, Christian. Ethique de l'existence post-capitaliste: pour un militantisme existentiel. Paris: Le Cerf, 2009.

AUBENQUE, Pierre. Le problème de l'être chez Aristote: essai sur la problématique aristotélicienne. Paris: Presses universitaires de France, 2018

ARENDT, Hannah. L'humaine condition. Paris: Gallimard, 2012. ARISTÓTELES. A política. Trad. Nestor Silveira Chaves. Rio de Janeiro: Nova Fronteira, 2011.

BENVENISTE, Émile. O vocabulário das instituições indo-européias.

v. 1. Campinas: Ed. da UNICAMP, 1995

CHANTEAU, Jean-Pierre; LABROUSSE, Agnès. L 'institutionnalisme méthodologique d'Elinor Ostrom: quelques enjeux et controverses. Revue de la régulation. Capitalisme. Institutions, pouvoirs, n. 14, 2013.

CHARDEAUX, M. A. Les choses communes, $1^{\text {a }}$ ed.. Paris: LGDJ, 2006. COLLIOT-THÉLÈNE, Catherine. La Démocratie sans demos. Paris: PUF, 2011.

CORIAT, B. Coriat. De communs fonciers aux communs informationnels. Trait communs et différences. Intervenção no seminário internacional Propriété et Communs, les nouveaux enjeux de l'accès et de l'innovation partagés. París, 25 e 26 de abril de 2013.

DUGUIT, Lon. Manuel de droit constitutionnel. BiblioBazaar, LLC, 2009.

DURKHEIM, Emile. El socialismo. Madrid: Ediciones Akal, 1987.

DUSSOLIER, S.. Open source and copyleft. Authorship reconsidered?.

New York: Columbia Journal of Law and Arts, n 26, 2002-2003.

FOURNIER, Jacques. Economie des besoins ( $\left.L^{\prime}\right)$ : Une nouvelle approche du service public. Paris: Odile Jacob, 2013. 
GADREY, Jean. L'utilité sociale en question: à la recherche de conventions, de critères et de méthodes d'évaluation. Les dynamiques de l'économie sociale et solidaire, Paris, La Découverte, coll.«Recherches, p. 237-279, 2006. 2006 GORZ, A. Écologica. París: Galilée, 2007 GORZ, A. Gorz. L'Immatériel. Connaissance, valeur et capital. Paris: Galilée, 2003.

HARDIN, Garrett. The tragedy of the commons. science, v. 162, n. 3859, p. 1243-1248, 1968

HESS, Charlotte; OSTROM, Elinor. Understanding knowledge as a Commons. Massachusetts: MIT Press, 2007.

KEOHANE, Robert O.; OSTROM, Elinor. Local commons and global interdependence. Londres: Sage, 1994.

LAVAL, Christian; DARDOT, Pierre. Común. $1^{\text {a }}$ ed.. Barcelona: Gedisa, 2015.

MARX, Karl. Miséria da filosofia. Boitempo Editorial, 2017

OSTROM, Elinor. Governing the commons. Cambridge: Cambridge University Press, 2015.

PANNEKOEK, A. 'La propriété publique et la propriété commune'. Publicado inicialmente na revista Western Socialist, novembro de 1947. Disponível em: 〈http://bataillesocialiste.wordpress.com> PEKKA, Himanen; LINUS, Torvalds; MANUEL, Castello. The hacker ethic and the spirit of the information age. Londres: Secker \& Warburg, 2001.

PNUD. Índices e indicadores de desarrollo humano 2018. Disponível em .<http://hdr.undp.org/sites/default/files/2018_human_development_s tatistical_update_es.pdf >. Acesso em 10 mai. 2019.

REVEL, J. Produire de la subjectivité, produire du commun: trois difficultés et um post-scriptum un peu long sur ce que le commun n'est pas. Seminário Du publica au commun. Sessão de 5 de dezembro de 2010. 
RHEINGOLD, Howard. The virtual community: Homesteading on the electronic frontier. MIT press, 2000.

SAINT-SIMON, Henri. El sistema industrial. Madrid: Edicones de la Revista de Trabajo, 1975.

THOMPSON, Edward P. The moral economy of the English crowd in the eighteenth century. Past \& present, n. 50, p. 76-136, 1971. TÖNNIES, Ferdinand. Communauté et société: catégories fondamentales de la sociologie pure. Presses universitaires de France, 2015.

TROTSKY, Leon. Terrorismo y comunismo: Slavoj Zizek presenta a Trotsky. Ediciones Akal, 2009.p. 91-92.

WELZER, Harald. Climate Wars: what people will be killed for in the 21 st century. $1^{\text {a }}$ ed.. Cambridge: John Wiley \& Sons, 2015.

WIENER, Norbert. Cibernética: ou controle e comunicação no animal e na máquina. São Paulo: Polígono, 1970.

XIFARAS, Mikhaïl. Le copyleft et la théorie de la propriété. Multitudes, n. 2, p. 50-64, 2010. 